\title{
Probiotic Lactobacillus sp. Strains Inhibit Growth, Adhesion, Biofilm Formation, and Gene Expression of Bacterial Vaginosis-Inducing Gardnerella vaginalis
}

\author{
Zhixiang Qian ${ }^{1,2,3}{ }^{\text {, Hui Zhu }}{ }^{1}$, Dan Zhao ${ }^{1}$, Ping Yang ${ }^{1}$, Fei Gao ${ }^{1}$, Chunyi Lu ${ }^{1}$, Yu Yin ${ }^{1}$, Shidong Kan ${ }^{1}$ \\ and Daijie Chen $1,2,3, *$
}

check for updates

Citation: Qian, Z.; Zhu, H.; Zhao, D.; Yang, P.; Gao, F.; Lu, C.; Yin, Y.; Kan, S.; Chen, D. Probiotic Lactobacillus sp. Strains Inhibit Growth, Adhesion, Biofilm Formation, and Gene Expression of Bacterial Vaginosis-Inducing Gardnerella vaginalis. Microorganisms 2021, 9, 728. https://doi.org/10.3390/ microorganisms 9040728

Academic Editor: Laurent Urios

Received: 19 February 2021

Accepted: 28 March 2021

Published: 31 March 2021

Publisher's Note: MDPI stays neutral with regard to jurisdictional claims in published maps and institutional affiliations.

Copyright: (c) 2021 by the authors. Licensee MDPI, Basel, Switzerland. This article is an open access article distributed under the terms and conditions of the Creative Commons Attribution (CC BY) license (https:// creativecommons.org/licenses/by/ $4.0 /)$.
1 College of Pharmacy, Shanghai Jiaotong University, Shanghai 200240, China; 820876094@sjtu.edu.cn (Z.Q.); julie19930@sjtu.edu.cn (H.Z.); 20135310341@sjtu.edu.cn (D.Z.); yp_930201@sjtu.edu.cn (P.Y.); feigao@sjtu.edu.cn (F.G.); luchunyi@sjtu.edu.cn (C.L.); yinyuly@sjtu.edu.cn (Y.Y.); chen_lab@sjtu.edu.cn (S.K.)

2 State Key Laboratory of Microbial Metabolism, Shanghai Jiao Tong University, Shanghai 200240, China

3 Shanghai Institute of Pharmaceutical Industry, China State Institute of Pharmaceutical Industry, Shanghai 201203, China

* Correspondence: cdj@sjtu.edu.cn

\begin{abstract}
Gardnerella vaginalis contributes significantly to bacterial vaginosis, which causes an ecological imbalance in vaginal microbiota and presents with the depletion of Lactobacillus sp. Lactobacillus supplementation was reported to be an approach to treat bacterial vaginosis. We investigated the applicability of three Lactobacillus sp. strains (Lactobacillus delbrueckii DM8909, Lactiplantibacillus plantarum ATCC14917, and Lactiplantibacillus plantarum ZX27) based on their probiotic abilities in vitro. The three candidate Lactobacillus sp. strains for bacterial vaginosis therapy showed distinct properties in auto-aggregation ability, hydrophobicity, adhesion to cervical epithelial cells, and survivability in $0.01 \%$ hydrogen peroxide. Lpb. plantarum ZX27 showed a higher yield in producing short-chain fatty acids and lactic acid among the three candidate strains, and all three Lactobacillus sp. strains inhibited the growth and adhesion of G. vaginalis. Furthermore, we discovered that the culture supernatant of Lactobacillus sp. exhibited anti-biofilm activity against G. vaginalis. In particular, the Lpb. plantarum ZX27 supernatant treatment decreased the expression of genes related to virulence factors, adhesion, biofilm formation, metabolism, and antimicrobial resistance in biofilm-forming cells and suspended cells. Moreover, Lactobacillus sp. decreased the upregulated expression of interleukin-8 in HeLa cells induced by G. vaginalis or hydrogen peroxide. These results demonstrate the efficacy of Lactobacillus sp. application for treating bacterial vaginosis by limiting the growth, adhesion, biofilm formation, and virulence properties of $G$. vaginalis.
\end{abstract}

Keywords: Lactobacillus; Gardnerella vaginalis; biofilm; gene expression; anti-inflammatory

\section{Introduction}

Bacterial vaginosis (BV) is a common infection of the female reproductive tract [1]. Based on Amsel criteria, BV prevalence was up to 8.7\% in Beijing (2010), 5.9\% in Shandong (2004), and 15.4\% in Sichuan (2004) [2]. BV is characterized by the replacement of beneficial lactobacilli and the augmentation of anaerobic pathogenic bacteria, such as Gardnerella vaginalis [3-5]. G. vaginalis is postulated as the initial pathogenic bacteria that adhere to the vaginal epithelium, where it requires the assistance of other anaerobes to promote BV development [6]. It is now accepted that biofilms in BV are strongly associated with $G$. vaginalis [7], and G. vaginalis-forming biofilms on the vaginal epithelium contribute to the poor cure rates of antimicrobial therapy [8].

The virulence factors of $G$. vaginalis include vaginolysin and sialidase (encoded by vly and sld, respectively) that contribute to BV formation [9]. Vaginolysin is a member of the cholesterol-dependent cytolysin family and acts as a hemolysin [10] by creating pores 
that alter cell integrity and shape, which is thought to disrupt local innate immunity, and thus, promote BV persistence [11]. Sialidase (also known as neuraminidase) is an enzyme that cleaves sialic acid from the terminal glycans of glycoproteins and is also present in cervicovaginal fluid [12]. Sialidase activity is a proposed biomarker for BV [13] and has been independently associated with adverse pregnancy outcomes, including intrauterine infections and preterm births [14].

Clindamycin and metronidazole are the standard drugs for BV [15]. However, their use is associated with antibiotic resistance and a high recurrence of the infection $[15,16]$. The biofilms of anaerobic pathogenic bacteria in vaginal microorganisms might be responsible for the treatment failure and recurrence of BV [17]. Adjuvant therapy with probiotics was recommended by experts, and some studies investigated the role of probiotics in BV treatment, including the use of probiotics alone and in combination with antibiotics [16]. A recent phase $2 \mathrm{~b}$ trial reported that Lactobacillus crispatus CTV-05 (Lactin-V) significantly reduced BV recurrence [18].

Lactobacillus sp. is the dominant species in about $70 \%$ of vaginas $(26.2 \%$ with $L$. crispatus, $6.3 \%$ with Lactobacillus gasseri, 5.3\% with Lactobacillus jensenii, and $34.1 \%$ with Lactobacillus iners in White/Asian women), and could promote vaginal health by suppressing the risk of BV [19]. The prevalence of these community types varies with race and ethnicity, with Black and Hispanic women more frequently hosting L. iners-dominant and diverse communities than White women, who more frequently host L. crispatus-dominant communities [20]. L. crispatus can repress the expression of vly and sld genes in G. vaginalis $[9,21]$, and Lactobacillus reuteri RC-14 produced the largest displacement of G. vaginalis in the biofilm [22]. Lactiplantibacillus plantarum 59 and Lactobacillus fermentum 137 were confirmed to exhibit anti-inflammatory effects against G. vaginalis and Candida albicans and to be capable of influencing the nuclear factor-kappaB signaling pathway [23]. Lpb. plantarum ZX27 is a typical probiotic microorganism found in old yogurt, and we previously demonstrated its antimicrobial effects against G. vaginalis and Escherichia coli [24]. However, to date, no study has investigated the anti-biofilm effect of $L p b$. plantarum against $G$. vaginalis, and the associated mechanisms remain unknown.

Accordingly, in the present study, we investigated the functions of two Lpb. plantarum strains (Lpb. plantarum ZX27 and Lpb. plantarum ATCC 14917) and one commercial lactic acid bacteria (LAB) strain (L. delbrueckii DM8909) and compared the probiotics based on their anti-adhesion, co-culture, and anti-biofilm activities against G. vaginalis. We further elucidated the possible mechanisms by evaluating the gene expression of associated parameters, including virulence factors, epithelial adhesion, biofilm formation, metabolism, and antimicrobial resistance of $G$. vaginalis. Finally, we assessed the anti-inflammatory activity of probiotics against G. vaginalis and oxidative stress (OS).

\section{Materials and Methods}

\subsection{Bacterial Strains, Media, Cell Lines, and Growth Conditions}

Three Lactobacillus sp. (Lpb. plantarum ZX27, isolated from Mongolian yogurt; Lpb. plantarum ATCC14917, purchased from the Guangdong culture collection center, Canton, Guangdong province, China; and L. delbrueckii DM8909, isolated from Dingjunsheng, Inner Mongolia Shuangqi Pharmaceutical Co. Ltd.) were selected to explore the effects of lactobacilli on G. vaginalis. ATCC49145 (purchased from the Guangdong culture collection center, Canton, Guangdong province, China) is a vaginolysin-producing strain [10]. Lactobacillus sp. and G. vaginalis were cultured in deMan, Rogosa, and Sharpe (MRS) broth and brainheart infusion $(\mathrm{BHI})$ broth supplemented with yeast extract $(1 \%)$, maltose $(0.1 \%)$, glucose $(0.1 \%)$, and horse serum $(10 \%)$ (BHIs), respectively, at $37^{\circ} \mathrm{C}$ under anaerobic conditions in an anaerobic system (Ruskinn Technology, Ltd., Bridgend, UK). HeLa cells, a cervical epithelial cell line, were cultured in Dulbecco's modified Eagle medium (DMEM; HyClone, Logan, UT, USA), and supplemented with 10\% fetal bovine serum (Gibco, Gaithersburg, MD, USA) and 1\% antibiotics (final concentrations: 100 units $/ \mathrm{mL}$ penicillin and $100 \mu \mathrm{g} / \mathrm{mL}$ 
streptomycin) (Gibco) at $37^{\circ} \mathrm{C}$ in a cell incubator (Thermo Fisher Scientific, Waltham, MA, USA) under a $5 \% \mathrm{CO}_{2}$ atmosphere.

2.2. Investigating the Auto-Aggregation Ability, Hydrophobicity, Adhesion Ability to HeLa Cells and Survivability in $0.01 \% \mathrm{H}_{2} \mathrm{O}_{2}$ of Three Candidate Strains

All three LAB strains were assessed in terms of the following characteristics: autoaggregation ability, hydrophobicity, adhesion to HeLa cells, and survivability in a $0.01 \%$ $\mathrm{H}_{2} \mathrm{O}_{2}$ environment.

Auto-aggregation assay was adapted from Pessoa et al. [25]. For the auto-aggregation assay, all Lactobacillus sp. strains were grown in MRS broth for $12 \mathrm{~h}$. After centrifugation $\left(10,000 \times g, 10 \mathrm{~min}\right.$, at $\left.4{ }^{\circ} \mathrm{C}\right)$, the cell pellets were resuspended, washed twice with $0.01 \mathrm{M}$ phosphate-buffered saline (PBS), and resuspended to $1 \times 10^{8}$ Colony-Forming Unit $/ \mathrm{mL}$ $(\mathrm{CFU} / \mathrm{mL})$ in the same solution. The suspensions were vortexed and incubated at $37^{\circ} \mathrm{C}$ for $4 \mathrm{~h}$, and an aliquot $(1 \mathrm{~mL})$ from the top of the suspension was carefully removed for assessment of the optical density at $600 \mathrm{~nm}\left(\mathrm{OD}_{600}\right)$ using a spectrophotometer (UV1100; Mapada Instruments Co., Ltd., Shanghai, China). The formula for calculating autoaggregation is as follows: auto-aggregation $(\%)=\left(1-\mathrm{A}_{t} / \mathrm{A}_{0}\right) \times 100 \%$, where $\mathrm{A}_{0}$ indicates the absorbance at $0 \mathrm{~h}$, and $\mathrm{A}_{\mathrm{t}}$ indicates the absorbance at $4 \mathrm{~h}$. The auto-aggregation assay for the three lactobacilli was performed in triplicate.

We used microbial adhesion to hydrocarbons to determine the degree of hydrophobicity, which was adapted from Rong et al. [26]. Xylene was used as the solvent, and lactobacilli strains were prepared similarly to the auto-aggregation assay. The lactobacilli strains were resuspended in a $0.1 \mathrm{M}$ potassium nitrate $(\mathrm{pH}$ 6.2) solution and washed twice with $0.01 \mathrm{M}$ PBS. The solution was then adjusted to an $\mathrm{OD}_{600}$ of $0.5 \mathrm{~A}_{0}$. We mixed $3 \mathrm{~mL}$ of each Lactobacillus sp. suspension with $1 \mathrm{~mL}$ of xylene prior to vortex for $10 \mathrm{~s}$, and incubated them at room temperature $\left(25^{\circ} \mathrm{C}\right)$ for $10 \mathrm{~min}$. The mixtures were then vortexed for $2 \mathrm{~min}$ prior to incubation at room temperature $\left(25^{\circ} \mathrm{C}\right)$ for $20 \mathrm{~min}$ for phase separation. The aqueous phase was gently removed to measure its absorbance at $600 \mathrm{~nm}\left(\mathrm{~A}_{1}\right)$. The surface hydrophobicity $(\%)$ was calculated as $\left(1-\mathrm{A}_{1} / \mathrm{A}_{0}\right) \times 100 \%$. The hydrophobicity assay for the three lactobacilli was performed in triplicate.

Adhesion to HeLa cells was assayed according to the methods of [27]. Briefly, HeLa cells covering the bottom of a 12-well cell plate were washed twice with pre-warmed PBS. Bacterial cells $\left(10^{9} \mathrm{CFU}\right)$ were then resuspended in $0.5 \mathrm{~mL}$ DMEM and incubated with HeLa cells for $3 \mathrm{~h}$ at $37^{\circ} \mathrm{C}$, after which the epithelial cell cultures were removed and washed twice with pre-warmed PBS. Subsequently, $100 \mu \mathrm{L}$ of trypsin-Ethylene Diamine Tetraacetic Acid (EDTA) (1×; Invitrogen, Carlsbad, CA, USA) was added to each well and incubated for $10 \mathrm{~min}$ at $37^{\circ} \mathrm{C}$ to lyse the cells. PBS $(900 \mu \mathrm{L})$ was then added to the solution and mixed, and serial dilutions were performed, followed by incubation at $37^{\circ} \mathrm{C}$ for $24 \mathrm{~h}$. The adhesion ratio was calculated by comparing the number of adherent cells to the original bacterial suspension $\left(10^{9} \mathrm{CFU} / \mathrm{mL}\right)$. The number of adhered lactobacilli strains on the HeLa cells was calculated by comparing the number of adherent bacterial cells to the number of HeLa cells $\left(10^{6} /\right.$ well $)$. The adhesion of each of the three lactobacilli was tested in triplicate in three independent experiments.

Stress survival tests were performed in accordance to [27], with a slight modification. Briefly, based on estimations via the $\mathrm{OD}_{600}$ measurements, $10^{8} \mathrm{CFU} / \mathrm{mL}$ bacterial cells were resuspended in $1 \mathrm{~mL}$ of $0.01 \% \mathrm{H}_{2} \mathrm{O}_{2}$ and incubated at $37^{\circ} \mathrm{C}$ for $90 \mathrm{~min}$. The survival percentage was calculated by comparing the exact CFU (plate counts) before and after their addition to $0.01 \% \mathrm{H}_{2} \mathrm{O}_{2}$. PBS was used as a baseline, and the negative control was lactobacilli incubated in PBS. Each strain was tested three times, and each experiment was performed in triplicate.

\subsection{Short-Chain Fatty Acids (SCFAs) and Lactic Acid Analysis in Cell-Free Supernatants (CFS)}

CFS from the three Lactobacillus sp. strains were prepared as described in our previous study [24]. Briefly, Lactobacillus sp. was incubated in MRS broth for $24 \mathrm{~h}$ in an anaerobic culture device (Ruskinn Technology, Ltd.), followed by centrifugation $(8000 \times g$, 
$20 \mathrm{~min})$ and filtering $(0.22 \mu \mathrm{m})$. An evaluation of SCFAs and lactic acid in the CFS was performed according to the methods of [28]. The CFS $(400 \mu \mathrm{L})$ was added to $100 \mu \mathrm{L}$ of $50 \%$ aqueous sulfuric acid and $500 \mu \mathrm{L}$ of diethyl ether. After vortexing and centrifugation $(12,000 \times g, 10 \mathrm{~min})$, the extracted SCFAs and lactic acid extracted in the upper layer (diethyl ether) were analyzed by gas chromatography (GC-2010; Shimadzu, Kyoto, Japan), with 2-methylpentanoic acid as the internal standard. The chromatographic conditions were as follows: injection chamber temperature of $220^{\circ} \mathrm{C}$; injection volume of $1 \mu \mathrm{L}$; shunting ratio of 5:1; flow rate of $2 \mathrm{~mL} / \mathrm{min}$; column temperature of $100{ }^{\circ} \mathrm{C}$ reserved for $1 \mathrm{~min}, 5^{\circ} \mathrm{C} / \mathrm{min}$ increased to $170{ }^{\circ} \mathrm{C}, 30^{\circ} \mathrm{C} / \mathrm{min}$ increased to $230^{\circ} \mathrm{C}$ and reserved to $100^{\circ} \mathrm{C}$ in $2 \mathrm{~min}$; and flame ionization detector temperature of $250^{\circ} \mathrm{C}$. Three samples of the CFS from the three Lactobacillus spp. were tested.

\subsection{Co-Aggregation Assay}

A co-aggregation assay was adapted from Pessoa et al. [25]. For the co-aggregation assay, the Lactobacillus sp. suspension was prepared similarly to the auto-aggregation assay. The G. vaginalis suspension was prepared and standardized to $1 \times 10^{8} \mathrm{CFU} / \mathrm{mL}$ in $0.01 \mathrm{M}$ PBS. Each Lactobacillus sp. suspension $(1 \mathrm{~mL})$ was mixed with the same volume of G. vaginalis suspension, and the mixture was vortexed for $10 \mathrm{~s}$ prior to gravity sedimentation. Control tubes contained $2 \mathrm{~mL}$ of each bacterial suspension alone. The absorbance of the suspensions was read at $600 \mathrm{~nm}$ in a spectrophotometer after a 3-h incubation at $37^{\circ} \mathrm{C}$. Co-aggregation was calculated using the following formula: co-aggregation $(\%)=[(A x+A y) / 2-A(x+y)] /[(A x+A y) / 2] \%$, where $A x$ and $A y$ indicate the absorbance of strains in the control tubes, and $A(x+y)$ indicates the absorbance of the mixtures.

\subsection{Co-Culture Assay}

We used the bacterial co-culture technique described by Jang et al. [29] to evaluate the influence of Lactobacillus sp. on G. vaginalis growth. G. vaginalis $\left(10^{4} \mathrm{CFU} / \mathrm{mL}\right)$ was inoculated into $5 \mathrm{~mL}$ of BHI broth in the presence of three Lactobacillus sp. strains (at $10^{5}$, $10^{6}$, or $10^{7} \mathrm{CFU} / \mathrm{mL}$ ) for $24 \mathrm{~h}$. The broth absence of Lactobacillus sp. was chosen as the control.

We used a DNA rapid extraction kit (Sangon Biotech, Shanghai, China) to extract the total DNA from $1 \mathrm{~mL}$ of co-cultured suspension culture, followed by amplification of $1 \mu \mathrm{L}$ of DNA by real-time qPCR using the SYBR Green Real-Time PCR Master Mix (Toyobo, Osaka, Japan) on a StepOnePlus system (Applied Biosystems, Foster City, CA, USA) with specific primers (forward, 5'-GCGTCAGTAACAGCCCAGAG-3'; and reverse, $5^{\prime}$-GCTTGTAGGCGGTTCGTC-3') for G. vaginalis. The PCR conditions were as follows: $95^{\circ} \mathrm{C}$ for $1 \mathrm{~min}$, followed by 40 cycles of denaturation at $95^{\circ} \mathrm{C}$ for $15 \mathrm{~s}$, annealing at $55^{\circ} \mathrm{C}$ for $15 \mathrm{~s}$, and extension and fluorescent data collection at $72{ }^{\circ} \mathrm{C}$ for $45 \mathrm{~s}$. For melting curve analysis, the temperature was decreased from $95^{\circ} \mathrm{C}$ to $65^{\circ} \mathrm{C}$ at a rate of $0.1{ }^{\circ} \mathrm{C} / \mathrm{s}$, with the continuous acquisition of the fluorescence signal intensity. The data were analyzed using the Applied Biosystems software. The percentage inhibition rate in the co-culture was calculated using the following formula: $\%$ inhibition rate $=\left(1-1 / 2^{\Delta \Delta \mathrm{Ct}}\right) \times 100$. The experiments were performed twice in triplicate.

\subsection{Evaluation of Lactobacillus sp. for Antagonism of G. vaginalis Adhesion}

The antagonistic effects of the probiotics on G. vaginalis adherence to HeLa cells were assayed according to a method described by Pessoa et al. [25], with slight modifications. HeLa cells $\left(1 \times 10^{8}\right.$ cells $/ \mathrm{mL}$ in $1 \mathrm{~mL}$ of DMEM) were incubated in 12-well culture plates for $24 \mathrm{~h}$, followed by incubation with Lactobacillus sp. (at $10^{5}, 10^{7}, 10^{9} \mathrm{CFU} / \mathrm{mL}$ suspended in DMEM) or vehicle at $37^{\circ} \mathrm{C}$ in a cell incubator for $3 \mathrm{~h}$. The initial concentration of $G$. vaginalis was $10^{4} \mathrm{CFU} / \mathrm{mL}$ in the co-culture assay because G. vaginalis will grow in BHIs broth after a 24-h co-culture. The concentration of G. vaginalis used in the adhesion test was $10^{7} \mathrm{CFU} / \mathrm{mL}$, owing to the fact that the adhesion test only lasted $3 \mathrm{~h}$. The growth of the 
G. vaginalis can be ignored. The plates were then washed twice with PBS, and G. vaginalis $\left(1 \times 10^{7} \mathrm{CFU} / \mathrm{mL}\right.$ suspended in DMEM) was added and incubated at $37^{\circ} \mathrm{C}$ for another 3 h. The plates were then washed three times with PBS, and the inhibition rate of G. vaginalis attachment to the cells was assayed using the qPCR method described in [29].

\subsection{Effects of LAB CFS on G. vaginalis Biofilm Formation and Preformation}

The effects of Lactobacillus sp. CFS on biofilm formation was evaluated according to the methods of [30], with slight modifications. The CFS was prepared using the same procedure used for SCFA analysis. A 100- $\mu$ l aliquot of the CFS was added to $100 \mu \mathrm{L}$ BHIs broth containing $10^{5}$ to $10^{6} \mathrm{CFU}$ of G. vaginalis, with the control sample prepared by adding $100 \mu \mathrm{l}$ MRS broth instead of CFS. A 200- $\mu$ l volume of each sample was then transferred to a 96-well microtiter plate, following incubation at $37^{\circ} \mathrm{C}$ for $48 \mathrm{~h}$ in an anaerobic chamber (Ruskinn Technology, Ltd.). To assess the extent of biofilm formation in each microplate, the culture medium was discarded, and the microplate was washed twice with $200 \mu \mathrm{L}$ of PBS. The adherent biofilm cells were stained with $200 \mu \mathrm{L}$ of $0.1 \%(w / v)$ Crystal Violet for 15 min and rinsed twice with PBS. After removing the bound dye from the stained cells with $200 \mu \mathrm{L}$ of absolute ethyl alcohol, the amount of biofilm was quantified by measuring the $\mathrm{OD}_{600}$ of the solution with a spectrophotometer (BioTek, Winooski, VT, USA). There were five replicates prepared for each sample, and the experiment was performed in triplicate.

The assessment of the CFS effects on preformed G. vaginalis biofilm was performed according to the methods of [31], with small modifications. A G. vaginalis culture was performed in a 96-well microtiter plate with $200 \mu \mathrm{L}$ BHIs broth prior to incubation at $37^{\circ} \mathrm{C}$ for $48 \mathrm{~h}$. The culture supernatant was removed, and the cells were washed twice with PBS. CFS $(200 \mu \mathrm{L})$ was then added to each well prior to incubation at $37^{\circ} \mathrm{C}$ for $24 \mathrm{~h}$. Reductions in the biofilm formation were determined following the reference.

\subsection{Impact of Lactobacillus sp. CFS on G. vaginalis Gene Expression}

To investigate underlying anti-G. vaginalis mechanisms, we evaluated G. vaginalis genes in mRNA levels, which encode proteins related to virulence factors (HMPREF0424_0103 (vly), HMPREF0424_1109 (sld)), epithelial adhesion (HMPREF0424_0125 (pat)), biofilm formation (HMPREF0424_0821 (gtf)), metabolism (HMPREF0424_1297 (stp), HMPREF0424_1253 (atm), and HMPREF0424_1189 (itm)), and antimicrobial resistance (HMPREF0424_0156 (bcrA) and HMPREF0424_1122 ( $m d s)$ ), by reverse transcription PCR, according to the methods of [31]. G. vaginalis was grown at $37^{\circ} \mathrm{C}$ for $48 \mathrm{~h}$ in BHI broth, after which $500 \mu \mathrm{L}$ of $\mathrm{G}$. vaginalis suspension and $500 \mu \mathrm{L}$ of CFS were added to $4 \mathrm{~mL}$ of BHI broth and incubated anaerobically in an anaerobic system (Ruskinn Technology, Ltd.) at $37^{\circ} \mathrm{C}$ for $48 \mathrm{~h}$. In the control wells, the Lactobacillus sp. CFS were replaced with MRS broth. After incubation, the culture suspension was removed from the wells for RNA extraction from floating bacteria. Cells adhering to the plate wells were washed twice with sterile PBS, and the RNA was extracted from the biofilm. The total RNA was extracted using TRIzol (Beyotime, Beijing, China) according to manufacturer instructions, and the RNA concentration and purity were determined using a microplate reader (BioTek). The ReverTra Ace qPCR RT kit (Toyobo) was used to reverse transcribe $2 \mu \mathrm{g}$ of total RNA into cDNA.

We used qPCR to examine the effect of Lactobacillus sp. on target gene expression in G. vaginalis according to the methods of Reham Wasf et al. [31]. The cDNA was amplified by real-time qPCR using the SYBR Green Real-Time PCR Master Mix on a StepOnePlus system, with the primers listed in Supplementary Table S1. We designed the primers according to the available literature and the complete genome of $G$. vaginalis $409-05$. The PCR conditions were as follows: $95^{\circ} \mathrm{C}$ for $1 \mathrm{~min}$, followed by 40 cycles of denaturation at $95^{\circ} \mathrm{C}$ for $15 \mathrm{~s}$, annealing at $60{ }^{\circ} \mathrm{C}$ for $15 \mathrm{~s}$, and extension and fluorescent data collection at $72{ }^{\circ} \mathrm{C}$ for $45 \mathrm{~s}$. The data were analyzed using the Applied Biosystems software, and differences in the mRNA-expression levels were calculated after normalizing to the $16 \mathrm{~S}$ rRNA level. The results are expressed as fold change compared to the control group based on the analysis of $\Delta \Delta \mathrm{Ct}$ values. 


\subsection{Anti-Inflammatory Effects of Probiotic Bacteria on HeLa Cells}

The anti-inflammatory effects of probiotic bacteria on HeLa cells were evaluated according to the methods of $[32,33]$. G. vaginalis and Lactobacillus sp. $\left(10^{8} \mathrm{CFU} / \mathrm{mL}\right.$ of bacterial cells, final concentration) were resuspended in DMEM and incubated with HeLa cells for $3 \mathrm{~h}$; with HeLa cells treated with DMEM for $3 \mathrm{~h}$ used as a control. The treated HeLa cells were washed twice with pre-warmed PBS (pH 7.0) and detached from the culture plates, after which TRIzol reagent (Beyotime) was added, and cells were stored at $-80^{\circ} \mathrm{C}$ until further use for RNA extraction.

The influence of probiotics on G. vaginalis-induced immunoreaction was evaluated according to the methods of [32], with minor changes. The HeLa cells with G. vaginalis $\left(10^{8} \mathrm{CFU} / \mathrm{mL}\right)$ were incubated for $3 \mathrm{~h}$ in a $5 \% \mathrm{CO}_{2}$ incubator, followed by the addition of probiotic cultures up to a final concentration of $10^{8} \mathrm{CFU} / \mathrm{mL}$ prior to incubation for another $3 \mathrm{~h}$ at $37^{\circ} \mathrm{C}$ in a $\mathrm{CO}_{2}$ incubator. The cells were then treated with TRIzol reagent, as described, and untreated HeLa cells were chosen as a negative control.

Oxidative stress was induced in the HeLa cells by treatment with $0.5 \% \mathrm{H}_{2} \mathrm{O}_{2}$ [32] prior to incubation in a $5 \% \mathrm{CO}_{2}$ incubator for $3 \mathrm{~h}$. Freshly grown probiotic bacteria (with a final concentration of $10^{8} \mathrm{CFU} / \mathrm{mL}$ ) were resuspended in DMEM and added to each well and incubated for another $3 \mathrm{~h}$. The HeLa cells treated with the probiotic bacteria were washed twice with pre-warmed PBS (pH 7.0) and detached from the culture plates, followed by collection, as previously described. RNA extraction and real-time PCR were performed as described in Section 2.8 .

\subsection{Statistical Analysis}

The results were analyzed using the GraphPad Prism software (v.6.0; GraphPad Software, San Diego, CA, USA). All the results are expressed as the mean \pm SD or the mean. A one-way analysis of variance was performed, and comparisons of the data for statistical significance were performed by either Dunnett's multiple comparison test or Tukey's multiple comparison test. Statistical significance was defined as $p<0.05$ or fold change $(\geq 2$ or $\leq 0.5)$.

\section{Results}

3.1. Auto-Aggregation Ability, Hydrophobicity, Adhesion Ability to HeLa Cells and Survivability in $0.01 \% \mathrm{H}_{2} \mathrm{O}_{2}$ of Three Candidate Strains

Firstly, we compared the probiotic properties of the candidate strains. The autoaggregation ability and surface hydrophobicity of bacteria are two indirect methods for evaluating bacterial adhesion [34]. As shown in Table 1 and Supplementary Figure S1, L. delbrueckii DM8909 showed the strongest activity (51.5\%), and the auto-aggregation rates of Lpb. plantarum ATCC14917 and Lpb. plantarum ZX27 were $11.65 \%$ and $8.10 \%$, respectively. We observed moderate surface hydrophobicity in ATCC14917 and ZX27 (microbial adhesion to hydrocarbons $(\mathrm{MATH}) \in(33 \%-66 \%)$, whereas DM8909 exhibited low hydrophobicity (MATH $<33 \%$ ) at $29.07 \%$. HeLa cells were used to test the adhesion of Lactobacillus sp. to vaginal epithelial cells in vitro. DM8909 showed higher adhesion ability (35.96\%) than Lpb. plantarum ATCC14917 (8.89\%) and ZX27 (12.67\%), with 593, 147, and 209 bacilli adhered per HeLa cell, respectively. Additionally, the survivability rates of DM8909, ATCC14917, and ZX27 in $0.01 \%$ hydrogen peroxide $\left(\mathrm{H}_{2} \mathrm{O}_{2}\right)$ were $55.50 \%$, $11.97 \%$, and $91.12 \%$, respectively. Overall, DM8909 exhibited superior performance of adherence and co-culture with G. vaginalis. However, Lpb. plantarum ZX27 showed superior adherence, co-culture, and oxidation resistance compared to Lpb. plantarum ATCC14917. 
Table 1. Auto-aggregation ability, hydrophobicity, and adhesion ability to HeLa cells, and survivability in $0.01 \% \mathrm{H}_{2} \mathrm{O}_{2}$ of three candidate strains. (mean $\pm \mathrm{SD}, n=3$ ).

\begin{tabular}{cccc}
\hline Strain & $\begin{array}{c}\text { Auto-Aggregation } \\
\text { Ability (\%) }\end{array}$ & Hydrophobicity (\%) & \\
\hline $\begin{array}{c}\text { L. delbrueckii DM8909 } \\
\text { Lpb. plantarum }\end{array}$ & $51.50 \pm 4.10$ & $29.07 \pm 0.45$ \\
ATCC14917 & $11.65 \pm 1.49$ & $50.97 \pm 0.64$ \\
Lpb. plantarum ZX27 & $8.10 \pm 0.28$ & $44.07 \pm 0.15$ & \\
\hline & Adhesion to HeLa cells \\
Strain & Amount of & Survivability in \\
& Adhesion rate (\%) & lactobacilli & $\mathbf{0 . 0 1 \%} \mathbf{H}_{\mathbf{2}} \mathbf{O}_{\mathbf{2}} \mathbf{( \% )}$ \\
DM8909 & in each HeLa cell & \\
ATCC14917 & $35.96 \pm 6.81$ & $593 \pm 112$ & $55.5 \pm 2.55$ \\
ZX27 & $8.89 \pm 1.03$ & $147 \pm 17$ & $11.97 \pm 9.53$ \\
& $12.67 \pm 0.78$ & $209 \pm 13$ & $91.12 \pm 6.06$ \\
\hline
\end{tabular}

\subsection{SCFAs and Lactic Acid Levels in CFS}

SCFAs and lactic acid are important metabolites produced by Lactobacillus and Bifidobacterium and play an important role in maintaining intestinal health [35]. We analyzed the concentrations of six SCFAs and lactic acid in the CFS of cultured Lactobacillus sp. by gas chromatography to detect the differences in acid metabolites among candidate strains (Table 2). The other two L pb. plantarum strains produced more lactic acid, propionic acid, butyric acid, isobutyric acid, and valeric acid than Lactobacillus delbrueckii DM8909. In addition, the concentrations of SCFAs and lactic acid in CFS of Lpb. plantarum ZX27 were found $0.003 \mathrm{mM}$ (acetic acid), $0.106 \mathrm{mM}$ (lactic acid), $0.032 \mathrm{mM}$ (propionic acid), $0.060 \mathrm{mM}$ (butyric acid), $0.014 \mathrm{mM}$ (isobutyric acid), and $0.005 \mathrm{mM}$ (valeric acid) higher than Lpb. plantarum ATCC14917. DM8909 produced slightly higher amounts of acetic acid and isovaleric acid than the other strains.

Table 2. Concentrations of short-chain fatty acids (SCFAs) and lactic acid in the cell-free supernatants (CFS) of Lactobacillus sp. cultured under anaerobic conditions. (mean $\pm \mathrm{SD}, n=3$ ).

\begin{tabular}{cccccccc}
\hline \multirow{2}{*}{ Strain } & Acetic Acid & Lactic Acid & Propionic Acid & Butyric Acid & Isobutyric Acid & Valeric Acid & Isovaleric Acid \\
\cline { 2 - 8 } & $0.012 \pm 0.001$ & $6.513 \pm 0.034$ & $0.951 \pm 0.005$ & $0.977 \pm 0.003$ & $0.611 \pm 0.002$ & $0.431 \pm 0.002$ & $0.285 \pm 0.011$ \\
DM8909 & $0.054 \pm 0.031$ & $1.021 \pm 0.003$ & $1.06 \pm 0.004$ & $0.654 \pm 0.005$ & $0.464 \pm 0.003$ & $0.283 \pm 0.008$ \\
ATCC14917 & $0.008 \pm 0.001$ & $6.954 \pm 0.003$ & SCFAs and Lactic Acid (mM) \\
ZX27 & $0.011 \pm 0.001$ & $7.06 \pm 0.064$ & $1.053 \pm 0.003$ & $1.12 \pm 0.021$ & $0.668 \pm 0.008$ & $0.469 \pm 0.001$ & $0.282 \pm 0.007$ \\
\hline
\end{tabular}

\subsection{Interaction between Lactobacillus and G. vaginalis in Co-Aggregation, Co-Culture and Preventing Attachment}

Following $3 \mathrm{~h}$ of incubation with G. vaginalis, the co-aggregation value of the three lactobacilli ranged from $0.40 \%$ to $7.27 \%$. Specifically, the co-aggregation ability of DM8909 (7.27\%) and ZX27 (6.34\%) was similar, whereas ATCC14917 showed poor co-aggregation $(0.40 \%)$ (Figure 1A). The impact of the three lactobacilli on the growth of G. vaginalis was then evaluated in BHIs broth. A concentration series of $10^{5}, 10^{6}$, and $10^{7} \mathrm{CFU} / \mathrm{mL}$ Lactobacillus sp. was used in the co-culture assays. As shown in Figure 1B-D, at a concentration of $10^{5} \mathrm{CFU} / \mathrm{mL}$, the inhibition rates of DM8909, ATCC14917, and ZX27 were 80.06\%, $26.44 \%$, and $80.42 \%$, respectively $(24 \mathrm{~h})$. Additionally, at $10^{6} \mathrm{CFU} / \mathrm{mL}$, the inhibition rates of all three lactobacilli were $70.82 \%, 90.28 \%$, and $85.72 \%$, respectively. Furthermore, at $10^{7} \mathrm{CFU} / \mathrm{mL}$, all three lactobacilli showed excellent anti-G. vaginalis abilities, with inhibition rates over 98\%. Moreover, the suppressive effect of Lactobacillus sp. on G. vaginalis growth increased along with the increase in the number of Lactobacillus sp., with the biggest changes observed in ATCC14917 cells (ATCC14917 at $10^{5}$ CFU/mL showed an inhibition rate of $26.44 \%$, as compared with $90.28 \%$ at $10^{6} \mathrm{CFU} / \mathrm{mL}$ ) (Figure $1 \mathrm{C}$ ). 

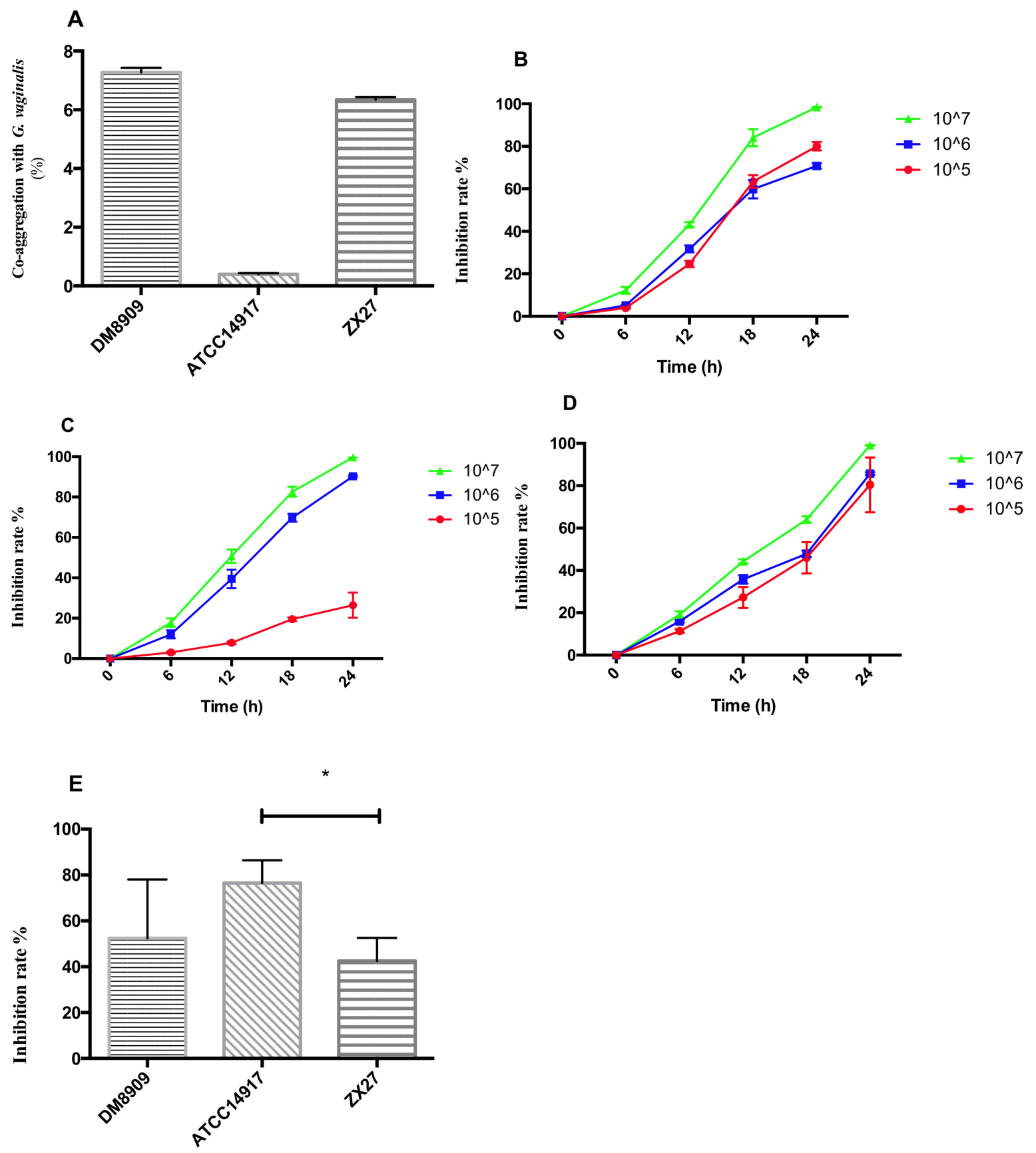

Figure 1. (A) Co-aggregation of three Lactobacillus sp. with G. vaginalis. Inhibition rates of G. vaginalis in a co-culture assay with (B) L. delbrueckii DM8909, (C) Lpb. plantarum ATCC14917, and (D) Lpb. plantarum ZX27. The initial concentration of G. vaginalis was $10^{4} \mathrm{CFU} / \mathrm{mL}$. (E) Inhibition rate of G. vaginalis adhesion following pre-adhesion by Lactobacillus sp. $\left(10^{9} \mathrm{CFU} / \mathrm{mL}\right)$. The initial concentration of G. vaginalis was $10^{7} \mathrm{CFU} / \mathrm{mL} .{ }^{*} p<0.05$. The data is represented as mean $\pm \mathrm{SD}$ $(n=3)$.

We then tested the protective effect of Lactobacillus sp. against G. vaginalis adhesion according to the competitive adhesion site of Lactobacillus sp. and G. vaginalis in HeLa cells. Preferential occupation of the adhesion site by Lactobacillus sp. would preclude the G. vaginalis attachment site, resulting in abortive binding to vaginal epithelial cells. The evaluation of the three lactobacilli concentrations $\left(10^{7}, 10^{8}\right.$, and $\left.10^{9} \mathrm{CFU} / \mathrm{mL}\right)$ revealed a protective effect only at the highest concentration $\left(10^{9} \mathrm{CFU} / \mathrm{mL}\right.$, corresponding to 100-fold 
of the concentration of $G$. vaginalis used). The results show average inhibition rates for DM8909, ATCC14917, and ZX27 of 52.39\%, 76.49\%, and 42.57\%, respectively (Figure 1E).

\subsection{Impact of CFS on the Formation and Disruption of G. vaginalis Biofilms}

The impact of CFS produced by Lactobacillus sp. on G. vaginalis biofilm was also evaluated to further study the inhibition effect of Lactobacillus sp. The CFS of the three lactobacilli caused a significant reduction $(p<0.05)$ in $G$. vaginalis biofilm formation and preformed biofilm (DM8909: 49.55\% and 44.91\%; ATCC14917: 31.08\% and 35.89\%; and ZX27: $45.79 \%$ and $40.84 \%$, respectively) (Figure $2 \mathrm{~A}, \mathrm{~B}$ ).

A

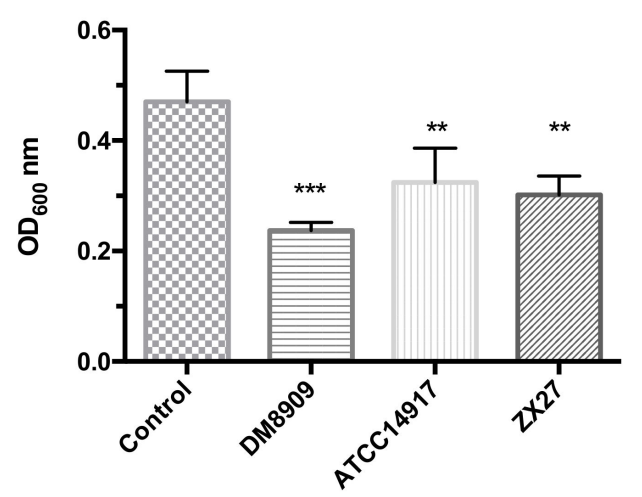

B

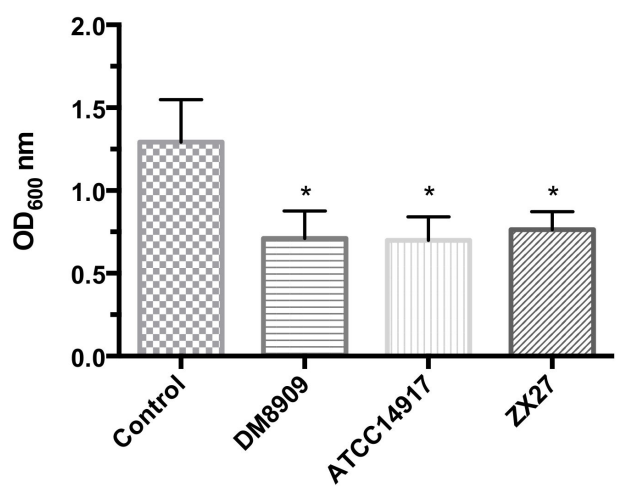

Figure 2. Impact of Lactobacillus sp. CFS on G. vaginalis. (A) Impact of CFS on G. vaginalis preformed biofilm. Optical density at $600 \mathrm{~nm}\left(\mathrm{OD}_{600}\right)$ of $\mathrm{G}$. vaginalis biofilm in the presence of CFS. (B) Impact of CFS on G. vaginalis biofilm formation. Control: G. vaginalis growth in BHIs broth. Values are showed as mean $\pm \mathrm{SD}(n=5) .{ }^{*} p<0.05,{ }^{* *} p<0.01,{ }^{* * *} p<0.001$ vs. control.

\subsection{Impact of CFS in Gene Expression in Planktonic and Biofilm Cells of G. vaginalis}

The CFS of the three LAB inhibit G. vaginalis growth and biofilm formation, according to the results of the present study and our previous work [24]. CFS contain Lactobacillus sp. metabolites, including SCFAs, $\mathrm{H}_{2} \mathrm{O}_{2}$, and bacteriocins [36]. In the present study, we used quantitative polymerase chain reaction (qPCR) to evaluate and compare the effect of LAB metabolites on G. vaginalis by exposing G. vaginalis to the CFS of the three Lactobacillus sp. (diluted 1:9 in BHIs) for $48 \mathrm{~h}$. We compared the expression of nine genes from planktonic and biofilm-forming cells with that of untreated cells. The selected genes are involved in virulence systems (vly and sld), pili proteins (pat), biofilm formation (gtf), metabolism (stp, atm, and itm), and antimicrobial resistance (bcr $A$ and $m d s)$.

Table 3 shows the fold changes in G. vaginalis at an mRNA level caused by the CFS of the three probiotic strains. DM8909 CFS upregulated three genes (sld, gtf, and stp) and did not impact the expression of the other six genes in planktonic cells. However, DM8909 CFS downregulated six genes (vly, sld, $g t f$, stp, $b c r A$, and $m d s)$, with no significant influence on the other three genes related to biofilm formation. ATCC14917 downregulated three genes $(g t f, b c r A$, and $m d s)$ in planktonic cells and seven genes $(v l y, s l d, p a t, g t f, s t p, b c r A$, and $m d s$ ) in biofilm cells. Moreover, ZX27 significantly reduced the expression of all genes in both cell types, except for $b c r A$ and $m d s$ in planktonic cells. These findings indicate that Lpb. plantarum ZX27 was the most effective for suppressing the expression of genes related to $G$. vaginalis pathogenicity. 
Table 3. Fold changes in the gene expression of G. vaginalis following exposure to Lactobacillus CFS. (Mean, $n=3$ ).

\begin{tabular}{|c|c|c|c|c|c|c|c|}
\hline \multirow{2}{*}{ Category } & \multirow{2}{*}{ Target Gene (Symbol) } & \multicolumn{3}{|c|}{ Fold change in Suspended Bacteria ${ }^{a}$} & \multicolumn{3}{|c|}{ Fold Change in Biofilm ${ }^{b}$} \\
\hline & & DM8909 & ATCC14917 & ZX27 & DM8909 & ATCC14917 & ZX27 \\
\hline \multirow{2}{*}{$\begin{array}{l}\text { Pathogenic } \\
\text { factor }\end{array}$} & HMPREF0424_0103 (vly) & 1.41 & 1.21 & $0.15^{*}$ & $0.17^{*}$ & $0.16^{*}$ & $0.14^{*}$ \\
\hline & HMPREF0424_1109 (sld) & $45.33^{*}$ & $10.33^{*}$ & $0.05^{*}$ & $0.25^{*}$ & $0.25^{*}$ & $0.01^{*}$ \\
\hline $\begin{array}{l}\text { Epithelial } \\
\text { adhesion }\end{array}$ & HMPREF0424_0125 (pat) & 1.20 & $2.65^{*}$ & $0.02^{*}$ & 0.57 & $0.36^{*}$ & $0.0001^{*}$ \\
\hline $\begin{array}{l}\text { Biofilm } \\
\text { formation }\end{array}$ & HMPREF0424_0821 (gtf) & $2.08^{*}$ & $0.29 *$ & $0.07^{*}$ & $0.27^{*}$ & $0.25^{*}$ & $0.17^{*}$ \\
\hline \multirow[t]{3}{*}{ Metabolism } & HMPREF0424_1297 (stp) & $2.21^{*}$ & 1.57 & $0.17^{*}$ & $0.38^{*}$ & $0.11^{*}$ & $0.04^{*}$ \\
\hline & HMPREF0424_1253 (atm) & 1.51 & 0.87 & $0.19^{*}$ & $2.08^{*}$ & 0.89 & $0.17^{*}$ \\
\hline & HMPREF0424_1189(itm) & 1.87 & 0.97 & $0.08^{*}$ & 0.72 & 0.72 & $0.07^{*}$ \\
\hline \multirow[t]{2}{*}{$\begin{array}{l}\text { Antimicrobial } \\
\text { resistance }\end{array}$} & HMPREF0424_0156 (bcrA) & 0.77 & $0.47^{*}$ & 1.64 & $0.10^{*}$ & $0.10^{*}$ & $0.30^{*}$ \\
\hline & HMPREF0424_1122 (mds) & 0.93 & $0.45^{*}$ & 1.83 & $0.17^{*}$ & $0.17^{*}$ & $0.39^{*}$ \\
\hline
\end{tabular}

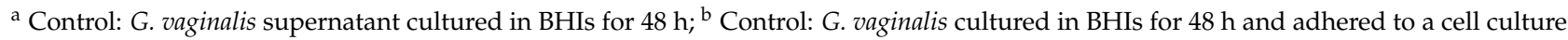
dish; * Denotes a statistically significant fold change $(\geq 2$ or $\leq 0.5)$.

\subsection{Anti-Inflammatory Activities of Lactobacillus sp.}

We then assessed the effects of different Lactobacillus sp. strains on interleukin (IL)8 production in HeLa cells. We found that G. vaginalis could significantly induce IL-8 expression; nevertheless, Lactobacillus sp. strains induced IL-8 expression less than G. vaginalis $(p<0.05)$ (Figure 3A). Additionally, IL-8 mRNA levels in HeLa cells exposed to the three Lactobacillus sp. strains did not differ significantly from those in the negative control $(p>0.05)$.
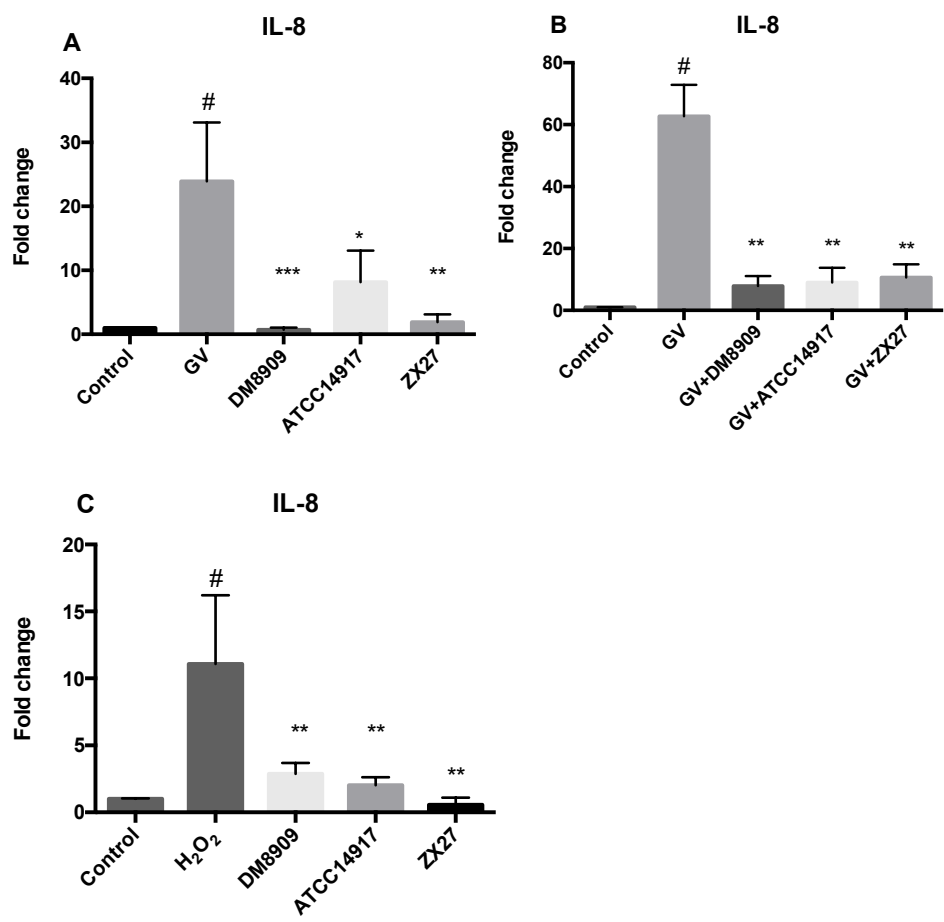

Figure 3. Regulation of pro-inflammatory IL-8 expression in HeLa cells by Lactobacillus sp. (A) IL-8 expression in HeLa cells simultaneously infected with G. vaginalis ATCC49145 (GV) and exposed to Lactobacillus sp. (B) IL-8 expression in HeLa cells infected with G. vaginalis ATCC49145 (GV), followed by Lactobacillus sp. treatment. (C) IL-8 expression under oxidative stress following treatment with Lactobacillus sp. Control: untreated HeLa cells. Data represent the mean $\pm \operatorname{SD}(n=3) .{ }^{*} p<0.05$ vs. Control; ${ }^{*} p<0.05,{ }^{* *} p<0.01,{ }^{* * *} p<0.001$ vs. $\mathrm{GV}$ or $\mathrm{H}_{2} \mathrm{O}_{2}$ alone. 
Moreover, we observed that the upregulated IL-8 expression in HeLa cells induced by G. vaginalis was significantly downregulated following subsequent post-treatment with probiotic Lactobacillus sp. ( $p<0.01$ ) (Figure 3B).

To further evaluate the anti-inflammatory activity of Lactobacillus sp. under oxidative stress, HeLa cells were exposed to $\mathrm{H}_{2} \mathrm{O}_{2}$ [32], which upregulated IL-8 expression. However, the following subsequent post-treatment with the three lactobacilli significantly reduced IL-8 expression in HeLa cells, compared with the $\mathrm{H}_{2} \mathrm{O}_{2}$ group $(p<0.05)$ (Figure $3 \mathrm{C}$ ).

\section{Discussion}

$\mathrm{BV}$ is among the most common vaginal conditions in women of child-bearing age worldwide. Optimal vaginal microbiota comprises a balanced mixture of more than 250 bacterial species [37]. Under certain conditions, changes in vaginal microbiota are always accompanied by a decrease in Lactobacillus sp. and an overgrowth of anaerobic bacteria. G. vaginalis is a major contributor to BV due to its virulence factors, including vaginolysin and sialidase $[9,13]$. Lactobacillus sp. have been proved to efficiently treat BV and reduce its recurrence by restoring vaginal microbiota [19,37-40].

Lactobacillus sp. exhibit antibacterial activity in different ways [25]. In the present study, we evaluated the probiotic ability and anti-inflammatory effects of three candidate lactobacilli and the pathways related to G. vaginalis adhesion, biofilm formation, and gene expression. L. delbrueckii DM8909 was a commercial strain isolated from Dingjunsheng (a live Lactobacillus capsule for vaginal use; Wanze Shuangqi). Our previous study confirmed Lpb. plantarum ZX27's anti-G. vaginalis activity [24], and in this report, Lpb. plantarum ATCC14917 was used as a control for Lpb. plantarum ZX27.

We initially compared the basal properties of the three lactobacilli. The auto-aggregation capacity is a crucial factor that allows probiotic strains to form floccules under adverse conditions [41]. Two Lpb. plantarum strains isolated from cocoa fermentation showed moderate auto-aggregation values of 33.44\% and 29.23\% [25], and Yanfeng et al. [42] reported $15 \mathrm{Lpb}$. plantarum strains showing auto-aggregation values ranging from $24.83 \%$ to $33.57 \%$. In the present study, L. delbrueckii DM8909 showed a notable auto-aggregation capacity of up to 51.5\%, whereas Lpb. plantarum ATCC14917 and ZX27 showed lower capacities of $11.65 \%$ and $8.1 \%$, respectively. It is likely that the auto-aggregation capacities of the two Lpb. plantarum strains in this study were inferior to those previously reported due to the different time periods evaluated. However, DM8909 had a lower MATH $(<33 \%)$ according to hydrophobicity testing, which was consistent with previous findings [42]. Moreover, we assessed the adhesion abilities of the three strains to HeLa cells in saturation coverage (over 1000 strains on one HeLa cell, $10^{9}$ CFU Lactobacillus sp. strains covered $10^{6} \mathrm{HeLa}$ cells). The number of Lactobacillus sp. to HeLa cells indicated the maximum number of Lactobacillus sp. on one cell $(>100)$, suggesting that all three strains possessed notable adhesive properties. Furthermore, ZX27 showed better survivability under oxidative stress, and the results reveal significantly enhanced resistance to $0.01 \% \mathrm{H}_{2} \mathrm{O}_{2}$ when compared with ATCC14917. Petrova et al. [27] tested three vaginal probiotic Lactobacillus sp. and found the survival rates of Lactobacillus rhamnosus GG, L. rhamnosus GR-1, and L. rhamnosus LC705 in 0.1\% (v/v) $\mathrm{H}_{2} \mathrm{O}_{2}$ ranging from $1.8 \%$ to $8.7 \%$. Additionally, we found that the probiotic properties were highly strain-specific, with ZX27 exhibiting moderate properties in hydrophobicity and adhesion. Bacterial colonization and adhesion are likely influenced by auto-aggregation [3]. Although ZX27 exhibited relatively poor auto-aggregation, it exhibited faster growth and a higher number of CFUs at the end of fermentation $(12 \mathrm{~h})\left(4 \times 10^{9} \mathrm{CFU} / \mathrm{mL}\right)$ compared to DM8909 $\left(5 \times 10^{8} \mathrm{CFU} / \mathrm{mL}\right)$ (Supplementary Figure S2).

The evaluation of the SCFAs and lactic acid in the CFS of ZX27 indicated that it produced the highest content of lactic acid (8.8\% higher than DM8909), propionic acid, butyric acid, isobutyric acid, and valeric acid. A low, acidic $\mathrm{pH}$ is generally considered to be a primary mechanism for maintaining the composition of healthy vaginal microflora [43]. Moreover, BV is characterized by a dramatic loss of lactic acid and greater concentrations of mixed SCFAs, including acetate, propionate, butyrate, and succinate [44]. In the present 
study, we found that ZX27 was a more appropriate candidate for BV therapy since this strain produced higher concentrations of propionic acid, butyric acid, isobutyric acid, valeric acid, and lactic acid than DM8909.

In the co-aggregation test, DM8909 and ZX27 had a significantly higher co-aggregation ability with G. vaginalis than ATCC14917 (Figure 1A). Additionally, the observed coaggregation with G. vaginalis in the present study $(0.40-7.27 \%)$ was lower than previous reports (43.15-44.61\%) [25]. The co-culture experiments showed that the original content of Lactobacillus sp. influenced the inhibition ability. With the content of $10^{7} \mathrm{CFU} / \mathrm{mL}$, all three lactobacilli efficiently inhibited G. vaginalis growth (inhibition rate $>98 \%$ ) (Figure 1B-D). These results were consistent with those of other studies, including Lpb. plantarum Os13 and Lpb. plantarum Kor14 inhibition of Listeria monocytogenes, E. coli, and Salmonella enterica serovar Enteritidis growth at different times with an initial Lactobacillus sp. content of $10^{7}$ $\mathrm{CFU} / \mathrm{mL}$ [45]. Additionally, Lactobacillus johnsonii LJ202 inhibited the growth of S. enterica serovar Enteritidis DMST7106 in a co-culture study [46], and another study reported that a 4-h co-culture with Lactobacillus gasseri eliminated G. vaginalis and Prevotella bivia [47]. Moreover, two commercially available probiotic strains (L. rhamnosus HN001 and Lactobacillus acidophilus GLA-14, alone or in combination (Respecta probiotic blend)) inhibit the growth of four different pathogens responsible for both BV (G. vaginalis and Atopobium vaginae) and aerobic vaginitis (Staphylococcus aureus and E. coli) in co-cultures [48]. Furthermore, Lpb. plantarum 86 and L. fermentum AI2 inhibit the growth of E. coli NG 502121 and S. aureus AY 507047 following co-culture [49]. We found that Lactobacillus sp. inhibited G. vaginalis adherence when HeLa cells were previously covered with Lactobacillus sp. (Figure 1E) and ATCC14917, showing the strongest inhibition to prevent $G$. vaginalis adherence. This result contrasts with reports indicating poor adherence of ATCC14917 to HeLa cells (Table 1). The stronger adhesive ability of ATCC14917 might be one of the possible explanations, and the poor co-aggregation ability of ATCC14917 with G. vaginalis may explain the higher adhesion inhibition rate of this Lactobacillus strain (Figure 1A,E). At a lower Lactobacillus sp. concentration of $10^{5} \mathrm{CFU} / \mathrm{mL}, \mathrm{G}$. vaginalis only showed good growth in a co-culture with ATCC14917. This might be related to the poor co-aggregation ability of ATCC14917 with G. vaginalis (Figure 1A,C). The poor co-aggregation ability of Lactobacillus resulted in a weak anti-pathogens ability with respect to a low probiotic number but provided stronger mucosal protection in the adhesion test. A previous study showed that L. crispatus significantly inhibits G. vaginalis adherence [21], and Lactobacillus sp. were capable of excluding and displacing urinary tract pathogens from SV-HUC-1 cells [50]. Additionally, Liu et al. [51] found that Lpb. plantarum CCFM 233 and Lpb. plantarum CCFM 231 strongly antagonized the adhesion to and invasion of HT-29 cell lines by enteroinvasive E. coli.

In addition to the antimicrobial activity of the three lactobacilli, we discovered that their respective CFS exhibited anti-biofilm activity against G. vaginalis. Mariya et al. [52] reported that the lectin-like protein 1 in L. rhamnosus GR-1 inhibits adhesion and biofilm formation in the key urogenital pathogen E. coli UTI89. In addition to its anti-biofilm formation activity, we found that the CFS destroyed G. vaginalis biofilm. This was supported by a previous study showing that L. rhamnosus GR-1 and L. reuteri RC-14 infiltrate G. vaginalis biofilms and cause bacterial cell death [53]. G. vaginalis biofilms tolerate 5- and 4-8-fold higher concentrations of $\mathrm{H}_{2} \mathrm{O}_{2}$ and lactic acid, respectively, than planktonic cultures [53]. In the present study, we demonstrated that Lactobacillus sp. were capable of eliminating biofilm and efficiently killing G. vaginalis.

To investigate the mechanism by which Lactobacillus sp. antagonizes G. vaginalis, we evaluated the expression of relevant genes encoding virulence factors and their association with adhesion, biofilm formation, metabolism, and antimicrobial resistance (Table 3). The vly and sld genes encode vaginolysin and sialidase, which are the main pathogenic factors of G. vaginalis. We found that vly and sld expression was downregulated in both planktonic and biofilm cells by the CFS of ZX27, indicating that Lactobacillus sp. CFS influences virulence factors produced by G. vaginalis. It is clear that Lactobacillus sp. metabolites affected the expression of pathogenic genes. A previous study demonstrated that $L$. 
crispatus directly downregulated the expression of vly in G. vaginalis UM241, a BV-positive strain [9]. Furthermore, exposure to CFS decreased the expression of pat, which encodes the fibril-associated protein (flp) pilus-assembly TadE/G-like family protein and might play an important role in its adhesion to vaginal epithelial cells [54]. These findings suggest that Lactobacillus sp. CFS might decrease the package of pilus in G. vaginalis to inhibit adhesion. Deconvolution microscopy showed changes in the structure and viability of biofilms in the presence of L. reuteri RC-14, accompanied by the loss of dense Gardnerella biofilm pods [22]. The $g t f$ gene encodes a glycosyltransferase, which is likely imperative for the biosynthesis of exopolysaccharide and critical for biofilm formation [54]. Except for DM8909, we found that CFS decreased the expression gtf in G. vaginalis. The stp, atm, and itm genes of G. vaginalis are involved in the metabolism of carbohydrates, amino acids, and ions, respectively (the function of these three genes are in Supplementary Table S1). In the present study, we found that ZX27 CFS decreased the expression of these genes, suggesting that Lactobacillus sp. CFS inhibited G. vaginalis metabolism. Furthermore, the expression of $b c r A$ and $m d s$ involved in antimicrobial resistance was downregulated in biofilm cells exposed to the CFS from all three lactobacilli. Interestingly, only ATCC14917 CFS downregulated $b c r A$ and $m d s$ expression in planktonic cells. In our previous study, Lactobacillus sp. directly inhibited $b c r A$ and $m d s$ expression [24]. This phenomenon might explain the better potency of probiotics combined with antibiotics for BV therapy compared to antibiotics alone [5]. Castro et al. [54] used RNA-seq technology to reveal upregulated expression of pat, $g t f, b c r A$, and $m d s$ in biofilm cells as compared with planktonic cells. In the present study, we found that Lactobacillus sp. decreased the expression of biofilmrelated genes in G. vaginalis and inhibited biofilm formation, agreeing with a previous study showing that lactobacilli infiltrate BV biofilms and result in bacterial death [53]. Notably, the CFS from DM8909 and ATCC14917 upregulated sld expression by 10-fold in planktonic cells, and DM8909 also upregulated $g t f$ and stp in suspended G. vaginalis cells. By contrast, these three genes were downregulated by DM8909 CFS in biofilm cells, with this downregulation also observed in sld and pat by ATCC14917 CFS. A possible explanation is that $G$. vaginalis responds differently to Lactobacillus sp. CFS in suspended and biofilm states. The CFS of L. delbrueckii DM8909 upregulated sld, gtf, and stp genes of G. vaginalis in planktonic form. One possible explanation is that free pathogenic bacteria prefer to make pathogenicity, while bacteria in the biofilm are more likely to survive in the presence of CFS from L. delbrueckii DM8909. This represents the first study reporting an altered expression of $G$. vaginalis genes associated with adhesion (pat), biofilm formation ( $g t f)$, metabolism (stp, atm, and itm), and antimicrobial-resistance (bcrA and $m d s$ ) by Lactobacillus sp.

We also evaluated the effect of Lactobacillus sp. on IL-8 production. Previous studies reported that $E$. coli-induced production of IL-8, a pro-inflammatory cytokine, is inhibited by Lactobacillus sp. in HT-29 cells [33], and Lpb. plantarum ATG-K2, ATG-K6, and ATGK8 lysates decrease lipopolysaccharide-induced production of IL-6 and tumor necrosis factor- $\alpha$ in murine macrophages [55]. In the present study, Lactobacillus sp. inhibited IL-8 production induced by $G$. vaginalis and $\mathrm{H}_{2} \mathrm{O}_{2}$. These results agree with a previous study showing that Lactobacillus sp. strains or Lpb. plantarum 59 and L. fermentum 137 CFS decreased IL-8 secretion in HeLa cells induced by G. vaginalis infection [23]. Additionally, Yang et al. [56] reported that Lpb. plantarum 200655 isolated from kimchi showed radical scavenging activity and lipid peroxidation-inhibition activity. In the present study, three lactobacilli displayed modulatory effects on IL-8 levels under oxidative stress conditions in HeLa cells. Further research on the anti-inflammatory function of Lactobacillus sp. in the vaginal environment is needed.

There are still some limitations in our studies. The adhesion and anti-inflammatory assays were performed in HeLa cells, which are a type of cancer cell; therefore, an assessment of these findings using normal vaginal epithelial cells may be more credible. Although experimental studies in mice have confirmed that Lactobacillus sp. can treat BV caused by G. vaginalis $[29,57]$, additional studies in other animal models and humans are needed to fully explore the mechanisms and safety of vaginal-use probiotics. 
In conclusion, we demonstrated that Lactobacillus sp. displayed four attributes related to anti-G. vaginalis activity: (1) growth inhibition, (2) adherence reduction via barrier function, (3) inhibition of anti-biofilm formation and attenuation of virulence factor expression, and (4) anti-inflammatory properties. Specifically, we showed that Lactobacillus sp. metabolites affected the expression of key genes, which is related to virulence factors, adhesion, biofilm formation, metabolism, and antimicrobial resistance in G. vaginalis. Multiple strains of Lactobacillus sp. may be used together for establishing vaginal eubiosis due to the specificity of probiotic strains. Our results identified Lpb. plantarum ZX27 as the possible candidate for further studies due to its satisfactory anti-G. vaginalis activity.

Supplementary Materials: The following are available online at https://www.mdpi.com/article/10 .3390 /microorganisms9040728/s1, Supplementary Table S1: Primer sequences used for qPCR assay, Supplementary Figure S1: Time-dependent auto-aggregation rate of the three tested Lactobacillus sp., Supplementary Figure S2: The growth curve of the three tested Lactobacillus sp.

Author Contributions: Z.Q. and D.C. contributed to the conception and design of the work; H.Z., D.Z., P.Y., F.G. and C.L. took part in in the experiment and reviewed the manuscript; Y.Y. provided technical support in the use of Applied Biosystems; S.K. modified the full text; Z.Q. wrote the main manuscript text and D.C. submitted the article. All authors have read and agreed to the published version of the manuscript.

Funding: This work was supported by grants from the National Key Research and Development Program of China (No. 2018YFA0901904), the National Natural Science Foundation of China (No. 81872775), and funding from the Consumer Products Group of Ministry of Industry and Information Technology of China (No. CEIEC-2020-ZM02-0165).

Institutional Review Board Statement: Not applicable.

Informed Consent Statement: Not applicable.

Data Availability Statement: All datasets generated for this study are included in the manuscript and/or the Supplementary Files.

Conflicts of Interest: The authors declare that they have no conflicts of interest.

\section{References}

1. Bohbot, J.M.; Daraï, E.; Bretelle, F.; Brami, G.; Daniel, C.; Cardot, J.M. Efficacy and safety of vaginally administered lyophilized Lactobacillus crispatus IP 174178 in the prevention of bacterial vaginosis recurrence. J. Gynecol. Obstet. Hum. Reprod. 2018, 47, 81-86. [CrossRef] [PubMed]

2. Kenyon, C.; Colebunders, R.; Crucitti, T. The global epidemiology of bacterial vaginosis: A systematic review. Am. J. Obstet. Gynecol. 2013, 209, 505-523. [CrossRef] [PubMed]

3. Hütt, P.; Lapp, E.; Štšepetova, J.; Smidt, I.; Taelma, H.; Borovkova, N.; Oopkaup, H.; Ahelik, A.; Rööp, T.; Hoidmets, D.; et al. Characterisation of probiotic properties in human vaginal lactobacilli strains. Microb. Ecol. Heal. Dis. 2016, 27. [CrossRef]

4. Breshears, L.M.; Edwards, V.L.; Ravel, J.; Peterson, M.L. Lactobacillus crispatus inhibits growth of Gardnerella vaginalis and Neisseria gonorrhoeae on a porcine vaginal mucosa model. BMC Microbiol. 2015, 15, 1-12. [CrossRef] [PubMed]

5. Grewal, N.; Mahajan, A. The Effect of Supplementation of Standard Antibiotic Therapy with Oral Probiotics for Bacterial Vaginosis. Int. J. Med. Dent. Sci. 2018, 7, 1628. [CrossRef]

6. Machado, A.; Cerca, N. Influence of biofilm formation by Gardnerella vaginalis and other anaerobes on bacterial vaginosis. J. Infect. Dis. 2015, 212, 1856-1861. [CrossRef] [PubMed]

7. Swidsinski, A.; Verstraelen, H.; Loening-Baucke, V.; Swidsinski, S.; Mendling, W.; Halwani, Z. Presence of a Polymicrobial Endometrial Biofilm in Patients with Bacterial Vaginosis. PLoS ONE 2013, 8, 4-8. [CrossRef] [PubMed]

8. Swidsinski, A.; Dörffel, Y.; Loening-Baucke, V.; Schilling, J.; Mendling, W. Response of Gardnerella vaginalis biofilm to 5 days of moxifloxacin treatment. FEMS Immunol. Med. Microbiol. 2011, 61, 41-46. [CrossRef] [PubMed]

9. Castro, J.; Paula, A.; Elisa, M.; Cerca, N. Anaerobe Lactobacillus crispatus represses vaginolysin expression by BV associated Gardnerella vaginalis and reduces cell cytotoxicity. Anaerobe 2018, 50, 60-63. [CrossRef]

10. Gelber, S.E.; Aguilar, J.L.; Lewis, K.L.T.; Ratner, A.J. Functional and phylogenetic characterization of vaginolysin, the humanspecific cytolysin from Gardnerella vaginalis. J. Bacteriol. 2008, 190, 3896-3903. [CrossRef] [PubMed]

11. Nowak, R.G.; Randis, T.M.; Desai, P.; He, X.; Robinson, C.K.; Rath, J.; Glover, E.D.; Ratner, A.J.; Ravel, J.; Brotman, R.M. Higher levels of a cytotoxic protein, vaginolysin, in Lactobacillus-deficient community state types at the vaginal mucosa. Physiol. Behav. 2019, 176, 139-148. [CrossRef] 
12. Hardy, L.; Jespers, V.; Van Den Bulck, M.; Buyze, J.; Mwambarangwe, L.; Musengamana, V.; Vaneechoutte, M.; Crucitti, T. The presence of the putative Gardnerella vaginalis sialidase A gene in vaginal specimens is associated with bacterial vaginosis biofilm. PLoS ONE 2017, 12, 1-11. [CrossRef]

13. Lopes Dos Santos Santiago, G.; Deschaght, P.; El Aila, N.; Kiama, T.N.; Verstraelen, H.; Jefferson, K.K.; Temmerman, M.; Vaneechoutte, M. Gardnerella vaginalis comprises three distinct genotypes of which only two produce sialidase. Am. J. Obstet. Gynecol. 2011, 204, 450.e1-450.e7. [CrossRef]

14. Cauci, S.; Culhane, J.F. High sialidase levels increase preterm birth risk among women who are bacterial vaginosispositive in early gestation. Am. J. Obstet. Gynecol. 2011, 204, 142.e1-142.e9. [CrossRef]

15. Donders, G.G.; Zodzika, J.; Rezeberga, D. Treatment of bacterial vaginosis: What we have and what we miss. Expert Opin. Pharmacother. 2014, 15, 645-657. [CrossRef]

16. Li, C.; Wang, T.; Li, Y.; Zhang, T.; Wang, Q.; He, J.; Wang, L.; Li, L.; Yang, N.; Fang, Y. Probiotics for the treatment of women with bacterial vaginosis: A systematic review and meta-analysis of randomized clinical trials. Eur. J. Pharmacol. 2019, 864, 172660. [CrossRef]

17. Muzny, C.A.; Schwebke, J.R. Biofilms: An Underappreciated Mechanism of Treatment Failure and Recurrence in Vaginal Infections. Clin. Infect. Dis. 2015, 61, 601-606. [CrossRef] [PubMed]

18. Cohen, C.R.; Wierzbicki, M.R.; French, A.L.; Morris, S.; Newmann, S.; Reno, H.; Green, L.; Miller, S.; Powell, J.; Parks, T.; et al. Randomized Trial of Lactin-V to Prevent Recurrence of Bacterial Vaginosis. N. Engl. J. Med. 2020, 382, 1906-1915. [CrossRef] [PubMed]

19. Petrova, M.I.; Lievens, E.; Malik, S.; Imholz, N.; Lebeer, S. Lactobacillus species as biomarkers and agents that can promote various aspects of vaginal health. Front. Physiol. 2015, 6, 1-18. [CrossRef] [PubMed]

20. Tortelli, B.A.; Lewis, W.G.; Allsworth, J.E.; Member-Meneh, N.; Foster, L.R.; Reno, H.E.; Peipert, J.F.; Fay, J.C.; Lewis, A.L. Associations between the vaginal microbiome and Candida colonization in women of reproductive age. Am. J. Obstet. Gynecol. 2020, 222, 471.e1-471.e9. [CrossRef] [PubMed]

21. Castro, J.; Alves, P.; Sousa, C.; Cereija, T.; França, Â. Using an in-vitro biofilm model to assess the virulence potential of Bacterial Vaginosis or non- Bacterial Vaginosis Gardnerella vaginalis isolates. Nat. Publ. Gr. 2015, 5, 1-10. [CrossRef]

22. Saunders, S.; Bocking, A.; Challis, J.; Reid, G. Effect of Lactobacillus challenge on Gardnerella vaginalis biofilms. Colloids Surf. B Biointerfaces 2007, 55, 138-142. [CrossRef]

23. Santos, C.M.A.; Pires, M.C.V.; Leão, T.L.; Silva, A.K.S.; Miranda, L.S.; Martins, F.S.; Silva, A.M.; Nicoli, J.R. Anti-inflammatory effect of two Lactobacillus strains during infection with Gardnerella vaginalis and Candida albicans in a Hela cell culture model. Microbiology 2018, 164, 349-358. [CrossRef] [PubMed]

24. Qian, Z.; Zhao, D.; Yin, Y.; Zhu, H.; Chen, D. Antibacterial Activity of Lactobacillus Strains Isolated from Mongolian Yogurt against Gardnerella vaginalis. BioMed Res Int. 2020, 10, 1-9. [CrossRef] [PubMed]

25. Pessoa, W.F.B.; Melgaço, A.C.C.; De Almeida, M.E.; Ramos, L.P.; Rezende, R.P.; Romano, C.C. In Vitro Activity of Lactobacilli with Probiotic Potential Isolated from Cocoa Fermentation against Gardnerella vaginalis. Biomed Res. Int. 2017, 2017, 3264194. [CrossRef]

26. Rong, J.; Zheng, H.; Liu, M.; Hu, X.; Wang, T.; Zhang, X.; Jin, F.; Wang, L. Probiotic and anti-inflammatory attributes of an isolate Lactobacillus helveticus NS8 from Mongolian fermented koumiss Microbe-host interactions and microbial pathogenicity. BMC Microbiol. 2015, 15, 1-11. [CrossRef] [PubMed]

27. Petrova, M.I.; Macklaim, J.M.; Wuyts, S.; Verhoeven, T.; Vanderleyden, J.; Gloor, G.B.; Lebeer, S.; Reid, G. Comparative genomic and phenotypic analysis of the vaginal probiotic Lactobacillus rhamnosus GR-1. Front. Microbiol. 2018, 9, 1-12. [CrossRef] [PubMed]

28. Zhao, D.; Zhu, H.; Gao, F.; Qian, Z.; Mao, W.; Yin, Y.; Tan, J.; Chen, D. Antidiabetic effects of selenium-enriched Bifidobacterium longum DD98 in the type 2 diabetes model of mice. Food Funct. 2020, 6528-6541. [CrossRef] [PubMed]

29. Jang, S.E.; Jeong, J.J.; Choi, S.Y.; Kim, H.; Han, M.J.; Kim, D.H. Lactobacillus rhamnosus HN001 and Lactobacillus acidophilus La-14 attenuate Gardnerella vaginalis-infected bacterial vaginosis in mice. Nutrients 2017, 9, 531. [CrossRef] [PubMed]

30. Jeong, D.; Kim, D.H.; Song, K.Y.; Seo, K.H. Antimicrobial and anti-biofilm activities of Lactobacillus kefiranofaciens DD2 against oral pathogens. J. Oral Microbiol. 2018, 10. [CrossRef] [PubMed]

31. Wasfi, R.; Abd El-Rahman, O.A.; Zafer, M.M.; Ashour, H.M. Probiotic Lactobacillus sp. inhibit growth, biofilm formation and gene expression of caries-inducing Streptococcus mutans. J. Cell. Mol. Med. 2018, 22, 1972-1983. [CrossRef] [PubMed]

32. Devi, S.M.; Kurrey, N.K.; Halami, P.M. In vitro anti-inflammatory activity among probiotic Lactobacillus species isolated from fermented foods. J. Funct. Foods 2018, 47, 19-27. [CrossRef]

33. Tuo, Y.; Song, X.; Song, Y.; Liu, W.; Tang, Y.; Gao, Y.; Jiang, S.; Qian, F.; Mu, G. Screening probiotics from Lactobacillus strains according to their abilities to inhibit pathogen adhesion and induction of pro-inflammatory cytokine IL-8. J. Dairy Sci. 2018, 101, 4822-4829. [CrossRef] [PubMed]

34. Rahman, M.M.; Kim, W.S.; Kumura, H.; Shimazaki, K.I. Autoaggregation and surface hydrophobicity of bifidobacteria. World J. Microbiol. Biotechnol. 2008, 24, 1593-1598. [CrossRef]

35. Raman, M.; Ambalam, P.; Doble, M. Probiotics and Bioactive Carbohydrates in Colon Cancer Management; Springer: Berlin/Heidelberg, Germany, 2016; ISBN 9788132225867.

36. Patil, P.S. Antimicrobial activity of vaginal lactobacilli against Gardnerella vaginalis and pathogens. Int. J. Adv. Res. Biol. Sci. 2016, 3, 200-207. Available online: http:/ / s-o-i.org/1.15/ijarbs-2016-3-5-29 (accessed on 7 May 2019). 
37. Walker, A.W. Microbiota of the Human Body. Implic. Health 2016, 902, 5-32. [CrossRef]

38. Homayouni, A.; Bastani, P.; Ziyadi, S.; Mohammad-Alizadeh-Charandabi, S.; Ghalibaf, M.; Mortazavian, A.M.; Mehrabany, E.V. Effects of probiotics on the recurrence of bacterial vaginosis: A review. J. Low. Genit. Tract Dis. 2014, 18, 79-86. [CrossRef]

39. Huang, H.; Song, L.; Zhao, W. Effects of probiotics for the treatment of bacterial vaginosis in adult women: A meta-analysis of randomized clinical trials. Arch. Gynecol. Obstet. 2014, 289, 1225-1234. [CrossRef]

40. Mastromarino, P.; Vitali, B.; Mosca, L. Bacterial vaginosis: A review on clinical trials with probiotics. New Microbiol. 2013, 36, 229-238. [CrossRef]

41. Nikolic, M.; Jovcic, B.; Kojic, M.; Topisirovic, L. Surface properties of Lactobacillus and Leuconostoc isolates from homemade cheeses showing auto-aggregation ability. Eur. Food Res. Technol. 2010, 231, 925-931. [CrossRef]

42. Tuo, Y.; Yu, H.; Ai, L.; Wu, Z.; Guo, B.; Chen, W. Aggregation and adhesion properties of 22 Lactobacillus strains. J. Dairy Sci. 2013, 96, 4252-4257. [CrossRef]

43. Haya, J.; García, A.; López-Manzanara, C.; Balawi, M.; Haya, L. Importance of Lactic Acid in Maintaining Vaginal Health: A Review of Vaginitis and Vaginosis Etiopathogenic Bases and a Proposal for a New Treatment. Open J. Obstet. Gynecol. 2014, 4, 787-799. [CrossRef]

44. Aldunate, M.; Srbinovski, D.; Hearps, A.C.; Latham, C.F.; Ramsland, P.A.; Gugasyan, R.; Cone, R.A.; Tachedjian, G. Antimicrobial and immune modulatory effects of lactic acid and short chain fatty acids produced by vaginal microbiota associated with eubiosis and bacterial vaginosis. Front. Physiol. 2015, 6, 1-23. [CrossRef] [PubMed]

45. Ołdak, A.; Zielińska, D.; Rzepkowska, A.; Kołozyn-Krajewska, D. Comparison of Antibacterial Activity of Lactobacillus plantarum Strains Isolated from Two Different Kinds of Regional Cheeses from Poland: Oscypek and Korycinski Cheese. Biomed Res. Int. 2017, 2017, 6820369. [CrossRef] [PubMed]

46. Abhisingha, M.; Dumnil, J.; Pitaksutheepong, C. Selection of Potential Probiotic Lactobacillus with Inhibitory Activity against Salmonella and Fecal Coliform Bacteria. Probiotics Antimicrob. Proteins 2018, 10, 218-227. [CrossRef]

47. Atassi, F.; Brassart, D.; Grob, P.; Graf, F.; Servin, A.L. Lactobacillus strains isolated from the vaginal microbiota of healthy women inhibit Prevotella bivia and Gardnerella vaginalis in coculture and cell culture. FEMS Immunol. Med. Microbiol. 2006, 48, 424-432. [CrossRef]

48. Bertuccini, L.; Russo, R.; Iosi, F.; Superti, F. Effects of Lactobacillus rhamnosus and Lactobacillus acidophilus on bacterial vaginal pathogens. Int. J. Immunopathol. Pharmacol. 2017, 30, 163-167. [CrossRef]

49. Shah, N.; Patel, A.; Ambalam, P.; Holst, O.; Ljungh, A.; Prajapati, J. Determination of an antimicrobial activity of Weissella confusa, Lactobacillus fermentum, and Lactobacillus plantarum against clinical pathogenic strains of Escherichia coli and Staphylococcus aureus in co-culture. Ann. Microbiol. 2016, 66, 1137-1143. [CrossRef]

50. Tsai, C.C.; Lai, T.M.; Hsieh, Y.M. Evaluation of Lactobacilli for Antagonistic Activity Against the Growth, Adhesion and Invasion of Klebsiella pneumoniae and Gardnerella vaginalis. Indian J. Microbiol. 2019, 59, 81-89. [CrossRef]

51. Liu, X.; Liu, W.; Zhang, Q.; Tian, F.; Wang, G.; Zhang, H.; Chen, W. Screening of lactobacilli with antagonistic activity against enteroinvasive Escherichia coli. Food Control 2013, 30, 563-568. [CrossRef]

52. Petrova, M.I.; Lievens, E.; Verhoeven, T.L.A.; MacKlaim, J.M.; Gloor, G.; Schols, D.; Vanderleyden, J.; Reid, G.; Lebeer, S. The lectin-like protein 1 in Lactobacillus rhamnosus GR-1 mediates tissue-specific adherence to vaginal epithelium and inhibits urogenital pathogens. Sci. Rep. 2016, 6, 1-15. [CrossRef] [PubMed]

53. McMillan, A.; Dell, M.; Zellar, M.P.; Cribby, S.; Martz, S.; Hong, E.; Fu, J.; Abbas, A.; Dang, T.; Miller, W.; et al. Disruption of urogenital biofilms by lactobacilli. Colloids Surf. B Biointerfaces 2011, 86, 58-64. [CrossRef] [PubMed]

54. Castro, J.; França, A.; Bradwell, K.R.; Serrano, M.G.; Jefferson, K.K.; Cerca, N. Comparative transcriptomic analysis of Gardnerella vaginalis biofilms vs. planktonic cultures using RNA-seq. NPJ Biofilms Microbiomes 2017, 3, 1-7. [CrossRef]

55. Beck, B.R.; Park, G.S.; Lee, Y.H.; Im, S.; Jeong, D.Y.; Kang, J. Whole genome analysis of Lactobacillus plantarum strains isolated from kimchi and determination of probiotic properties to treat mucosal infections by Candida albicans and Gardnerella vaginalis. Front. Microbiol. 2019, 10, 1-13. [CrossRef]

56. Yang, S.J.; Lee, J.E.; Lim, S.M.; Kim, Y.J.; Lee, N.K.; Paik, H.D. Antioxidant and immune-enhancing effects of probiotic Lactobacillus plantarum 200655 isolated from kimchi. Food Sci. Biotechnol. 2019, 28, 491-499. [CrossRef] [PubMed]

57. Joo, H.M.; Hyun, Y.J.; Myoung, K.S.; Ahn, Y.T.; Lee, J.H.; Huh, C.S.; Han, M.J.; Kim, D.H. Lactobacillus johnsonii HY7042 ameliorates Gardnerella vaginalis-induced vaginosis by killing Gardnerella vaginalis and inhibiting NF-кB activation. Int. Immunopharmacol. 2011, 11, 1758-1765. [CrossRef] [PubMed] 